\title{
Article \\ Beyond Single-Cell Analysis of Metallodrugs by ICP-MS: Targeting Cellular Substructures
}

\author{
Audrey Galé ${ }^{1,2}$, Lukas Hofmann ${ }^{3}\left(\mathbb{D}\right.$, Nicola Lüdi ${ }^{4}$, Martin Nils Hungerbühler ${ }^{1,2}\left(D\right.$, Christoph Kempf ${ }^{1,2}$, \\ Johannes Thomas Heverhagen ${ }^{1,2}$, Hendrik von Tengg-Kobligk ${ }^{1,2}{ }^{\oplus}$, Peter Broekmann ${ }^{4, *}$ and Nico Ruprecht ${ }^{1,2, *}$
}

1 Department of Diagnostic, Interventional and Pediatric Radiology, Bern University Hospital, University of Bern, 3010 Bern, Switzerland; audrey.gale@students.unibe.ch (A.G.); martin.hungerbuehler@dbmr.unibe.ch (M.N.H.); christoph.kempf@dbmr.unibe.ch (C.K.); johannes.heverhagen@insel.ch (J.T.H.); hendrik.vontengg@dbmr.unibe.ch (H.v.T.-K.)

2 Department for BioMedical Research DBMR, University of Bern, 3008 Bern, Switzerland

3 Institute of Nanotechnology and Advanced Materials \& Department of Chemistry, Faculty of Exact Sciences, Bar-Ilan University, Ramat-Gan 5290002, Israel; hofmmal@biu.ac.il

4 Department of Chemistry, Biochemistry and Pharmaceutical Sciences (DCBP), University of Bern, 3012 Bern, Switzerland; nicola.luedi@unibe.ch

* Correspondence: peter.broekmann@unibe.ch (P.B.); nico.ruprecht@dbmr.unibe.ch (N.R.); Tel.: +41-(0)31-684-4317 (P.B.); +41-(0)31-632-4923 (N.R.)

\section{check for} updates

Citation: Galé, A.; Hofmann, L.; Lüdi, N.; Hungerbühler, M.N.; Kempf, C.; Heverhagen, J.T.; von Tengg-Kobligk, H.;

Broekmann, P.; Ruprecht, N. Beyond Single-Cell Analysis of Metallodrugs by ICP-MS: Targeting Cellular Substructures. Int. J. Mol. Sci. 2021, 22, 9468. https://doi.org/10.3390/ ijms22179468

Academic Editor: Giovanni Natile

Received: 2 August 2021

Accepted: 30 August 2021

Published: 31 August 2021

Publisher's Note: MDPI stays neutral with regard to jurisdictional claims in published maps and institutional affiliations.

Copyright: (C) 2021 by the authors. Licensee MDPI, Basel, Switzerland. This article is an open access article distributed under the terms and conditions of the Creative Commons Attribution (CC BY) license (https:/ / creativecommons.org/licenses/by/ $4.0 /)$.

\begin{abstract}
Platinum compounds such as cisplatin (cisPt) embody the backbone of combination chemotherapy protocols against advanced lung cancer. However, their efficacy is primarily limited by inherent or acquired platinum resistance, the origin of which has not been fully elucidated yet, although of paramount interest. Using single cell inductively coupled plasma mass spectrometry (SC-ICP-MS), this study quantifies cisPt in single cancer cells and for the first time in isolated nuclei. A comparison of cisPt uptake was performed between a wild type $(w t)$ cancer cell line and related resistant sublines. In both, resistant cells, wt cells, and their nuclei, cisPt uptake was measured at different incubation times. A lower amount of cisPt was found in resistant cell lines and their nuclei compared to wt cells. Moreover, the abundance of internalized cisPt decreased with increasing resistance. Interestingly, concentrations of cisPt found within the nuclei were higher than compared to cellular concentrations. Here, we show, that SC-ICP-MS allows precise and accurate quantification of metallodrugs in both single cells and cell organelles such as nuclei. These findings pave the way for future applications investigating the potency and efficacy of novel metallodrugs developed for cancer treatment.
\end{abstract}

Keywords: NSCLC; cisplatin; chemotherapy; single cell ICP-MS; cisplatin resistance; nuclear uptake

\section{Introduction}

Since the serendipitous discovery of cisplatin (cisPt) and its anticancer properties by Rosenberg in 1965 and its subsequent approval as therapeutic in 1978, numerous platinum compounds have been synthesized and tested. However, only two more platinum-based drugs were approved worldwide since then. These two drugs were carboplatin and oxaliplatin [1]. The group of Barnett Rosenberg discovered the robust antiproliferative effects of cisPt in the late 1960s. This antiproliferative effect was explained by a complex formation between $\mathrm{Pt}(\mathrm{II})$ and nitrogen atoms of nucleotide bases (platinum-DNA adducts), that ultimately induces kinks and partial unwinding of the DNA helix [2]. This conformational change in the DNA structure halts the cell cycle and initiates programmed cell death $[3,4]$. Passive diffusion was considered as the sole mechanism for cisPt entering the cell $[5,6]$. However, in recent years alternative uptake pathways such as the Copper transporter 1 (CTR1) was identified as an important transmembrane protein involved in cisPt uptake $[7,8]$. Furthermore, copper-extruding P-type ATPases were found to reduce 
the cytoplasmic or cellular cisPt concentration [9,10]. Recently, Planells-Cases et al. [11] described that loss of LRRC8A and LRRC8D subunits of the volume-regulated anion channel (VRAC) effects cisPt uptake. Thus, the mechanisms involved in acquired resistance to cisPt likely comprise a variety of transition metal transporters and other yet unknown proteins present in mammalian cells.

Inherent or acquired platinum resistance is a major limitation to improve long-term outcomes in cancer therapy. Recent discoveries described several novel resistance mechanisms [12-14], which are divided into two groups. The first group demonstrates an insufficient uptake of platinum into cancer cells thus resulting in a lower cisPt concentration in the cytoplasm and a reduced amount of platinum-DNA adducts. The second group of resistance mechanisms relies on a failure of the apoptosis initiation process due to erroneous platinum-DNA adduct formation. To overcome cisPt resistance in anti-cancer therapy numerous approaches have been pursued [14]. Unfortunately, none of these approaches was implemented into clinics so far [15]. Therefore, the newly proposed VRAC as an importing channel for cisPt and carboplatin provides a novel promising target circumventing platinum-drug resistance in cancer patients [16].

With nearly 1.5 million new cases diagnosed worldwide each year, lung cancer is the most frequent diagnosed cancer in humans, the most common, aggressive, and also deadliest type of cancer worldwide $[15,17]$. There are two main types of this disease, nonsmall cell lung cancer (NSCLC) and small cell lung cancer (SCLC). NSCLC accounts for 85\% of all cases and is the most common type of lung cancer [15]. The current five year survival rates are $15-20 \%$. Among patients with NSCLC, these rates reach $90 \%$ for stage 1 but drop below $10 \%$ for stage 4 . Among patients with SCLC, the rates are about $30 \%$ for limited disease and below $10 \%$ for extensive disease [18]. Chemoimmunotherapy is currently being explored to improve first-line chemotherapy doublets by adding, e.g., immune checkpoint inhibitors [19].

To date, different cisPt resistant cell lines of various cancer types have been described [20-22]. Recently, cisPt resistant A240286S (A24) NSCLC sublines have been established. Clinically relevant resistance grades showed resistance levels above $4.0 \mu \mathrm{M}$ cisPt. This resistance persisted even after more than one year in absence of cisPt. However, a correlation between cisPt resistance and expression level of VRAC transporter in the A24 cell line was not confirmed [23]. Thus, loss of the VRAC transporter is obviously not the primary origin of the cisPt resistance in A24 cells. Hence, these recent findings are conflicting with previously published studies for other cell lines [11,24-26]. These fundamental controversies demonstrate that acquisition of transition metal drug resistance remains enigmatic to us, albeit of paramount interest. Therefore, only a comprehensive understanding of the acquisition of resistance allows for a targeted precision treatment of patients suffering from deadly lung cancer metastasis.

Here, we show exemplary that implementation and development of single cell inductively coupled plasma mass spectrometry (SC-ICP-MS) have paved the way for a novel area of anti-cancer research. This analysis technique enables immediate detection and quantification of metal-based compounds on the level of single cells. Because each cell is unique, is in its own growth stage, and the cell population has a distribution of different cell volumes, the use of SC-ICP-MS is particularly useful in the context of these experiments. In this study, SC-ICP-MS has proven to be a robust alternative to conventional ICP-MS for the quantification of intracellular platinum. By applying this method, the cells dissolved in water and PBS remain intact, thus preventing the loss of intracellular metal due to membrane permeabilization [27]. In this present study, the accumulation of cisPt is quantified by means of SC-ICP-MS in sensitive, resistant, and for the first time in the nuclei of A24 cells. 


\section{Results}

\subsection{Determination of Intracellular cisPt in Wild Type (wt) and Resitant Cells Using SC-ICP-MS}

The concentration of cisPt was determined in sensitive A24 wt cells and cisPt resistant A24dPt8 (previously described as (D-) Pt8.0A24 [23]) single cells with cisPt exposure of $30 \mu \mathrm{M}$ for $0,2,4,8$, and $16 \mathrm{~h}$. After more than two years in culture lacking cisPt, the $\mathrm{IC}_{50}$ value of resistant A24 cells was re-evaluated and still revealed an $\mathrm{IC}_{50}$ of $12.74 \mu \mathrm{M}$. Figure 1 shows a representative section of the counts vs. measurements in sensitive A24 wt cells and resistant $\mathrm{A} 24 \mathrm{dPt} 8$ treated with $30 \mu \mathrm{M}$ cisPt for $16 \mathrm{~h}$, respectively.

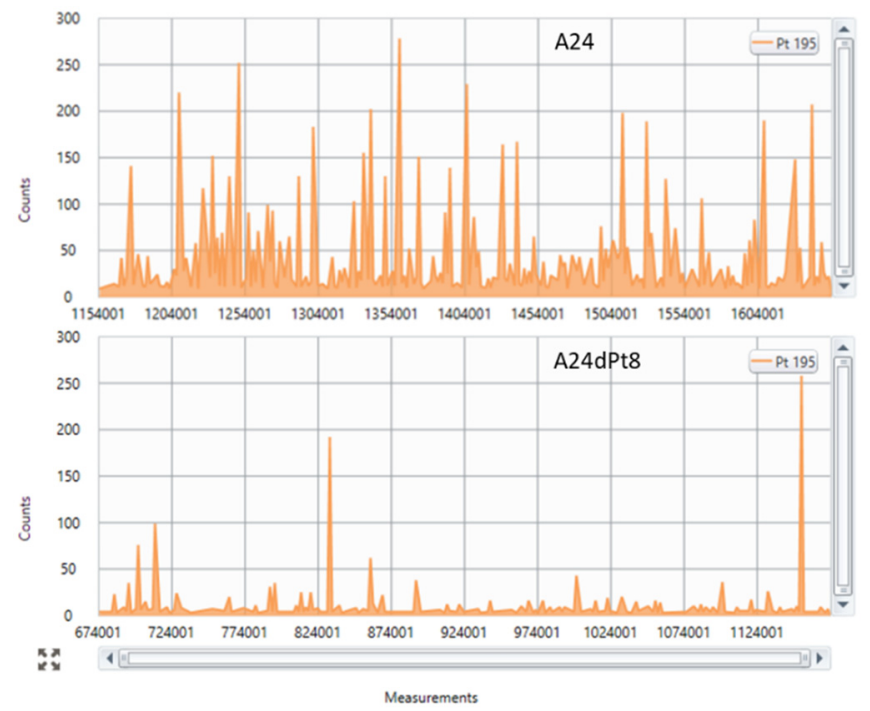

Figure 1. Single cell inductively coupled plasma mass spectrometry (SC-ICP-MS) representative sections of ( $\mathrm{Pt}$ 195) counts versus time traces in A24 cells and A24dPt8 cells. This figure shows real-time signal processing by Syngistix. It becomes apparent that less $\mathrm{Pt}$ is measured in resistant cells (bottom panel) than compared to wild type (wt) cells (top panel), independent of the measured time point ( $x$-axis). Each "intensity peak" represents accumulated Pt 195 counts for a defined time interval (dwell time) of $50 \mu \mathrm{s}$. Each time interval correspond to one "single measurement" ( $x$-axis). Assumption: each peak (measurement) corresponds to one individual entity analyzed (cell, cells aggregate).

Frequency distribution plots showing cisPt masses versus number of cell events (frequency) were obtained for $0,2,4,8$, and $16 \mathrm{~h}$ in presence of $30 \mu \mathrm{M}$ cisPt as shown in Figure 2A. Strikingly, longer incubation time, led to an increased amount of cisPt per A24 cells and in A24dPt8 cells. Additionally, varying cisPt amounts per cell were observed within A24 sublines, indicating that cisPt bioavailability of sensitive and resistant A24 cells varies within the cell population. The cellular concentration was calculated with the volume of A24 or A24dPt8 cells for each cell population (Figure 2B). Volumes up to $14,000 \mu \mathrm{m}^{3}$ were measured with a mean of $3800 \mu \mathrm{m}^{3}$ for A24 cells and $3200 \mu \mathrm{m}^{3}$ for A24dPt8 cells.

\subsection{Intracellular cisPt Concentration in A24 and A24dPt8 Cells}

Prior to the SC-ICP-MS measurement, the volume of the targeted cells had to be determined as basis for the proper calculation of the (mean) cellular cisPt concentration. SC-ICP-MS measurements, carried out for A24 and A24Pt8 cells, revealed an increasing trend of the cisPt concentration with exposure (incubation) time in case of A24 cells as well as A24dPt8. However, increase in intracellular Pt in A24dPt8 was much less prominent compared to the A24 cells. 

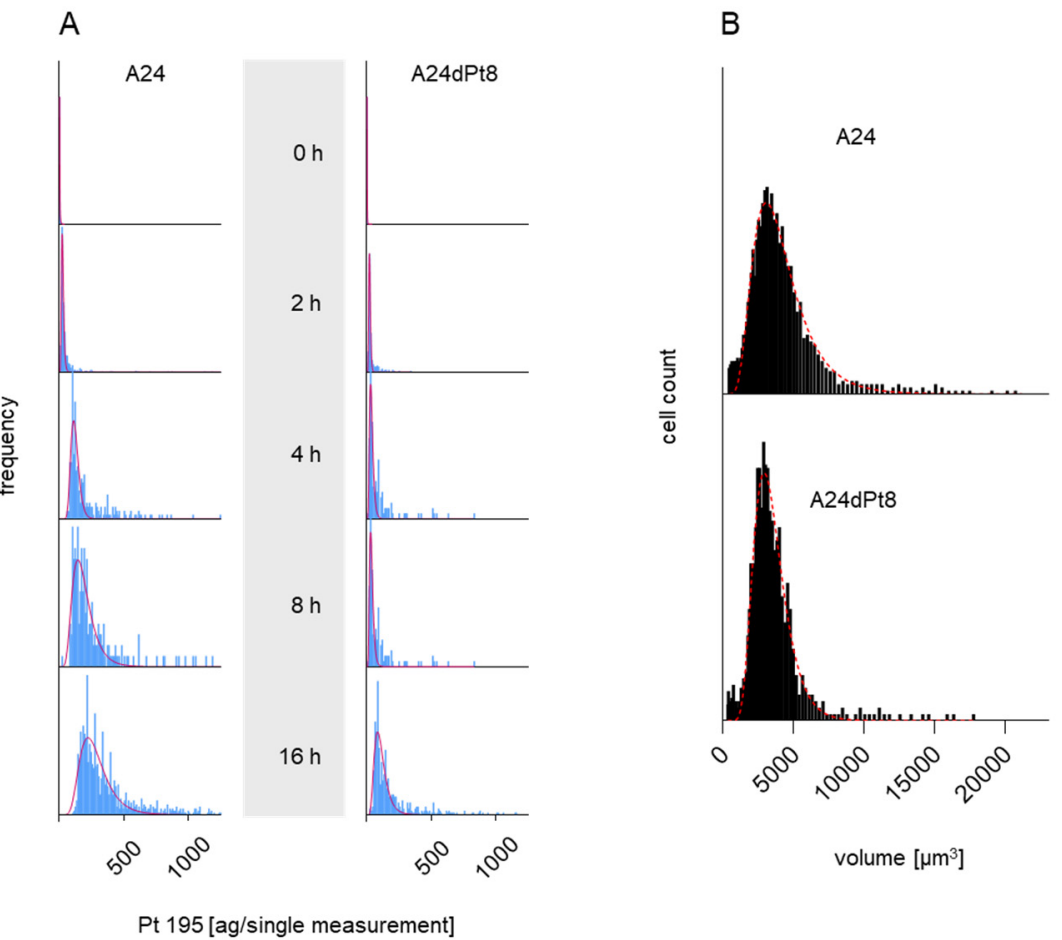

Figure 2. Frequency plot (integrated/fitted histogram; Syngistix-program PerkinElmer) of A24 and A24dPt8 cells (A) incubated with $30 \mu \mathrm{M}$ cisPt for $0,2,4,8$, and $16 \mathrm{~h}$. (B) Volume distribution vs. cell count (frequency). The red curves in (A) and (B) show the lognormal fit of the frequency.

Average cisPt concentration determined by SC-ICP-MS in A24 cells was $0.1 \pm 0.02 \mu \mathrm{M}$ cisPt per cell after an incubation time of $2 \mathrm{~h}$. Measurements at 4, 8, and $16 \mathrm{~h}$ of incubation, resulted in $0.17 \pm 0.02,0.29 \pm 0.04$, and $0.48 \pm 0.07 \mu \mathrm{M}$ cisPt/cell, respectively. In contrast, determination of cellular cisPt concentration in A24dPt8 revealed an average concentration of $0.06 \pm 0.02 \mu \mathrm{M}$ cisPt per cell after $2 \mathrm{~h}$. Measurement at $4 \mathrm{~h}$ showed an average of $0.09 \pm 0.02 \mu \mathrm{M}$ cisPt, at $8 \mathrm{~h} 0.16 \pm 0.02 \mu \mathrm{M}$ cisPt, and at $16 \mathrm{~h} 0.24 \pm 0.06 \mu \mathrm{M}$ cisPt/cell (Figure 3).

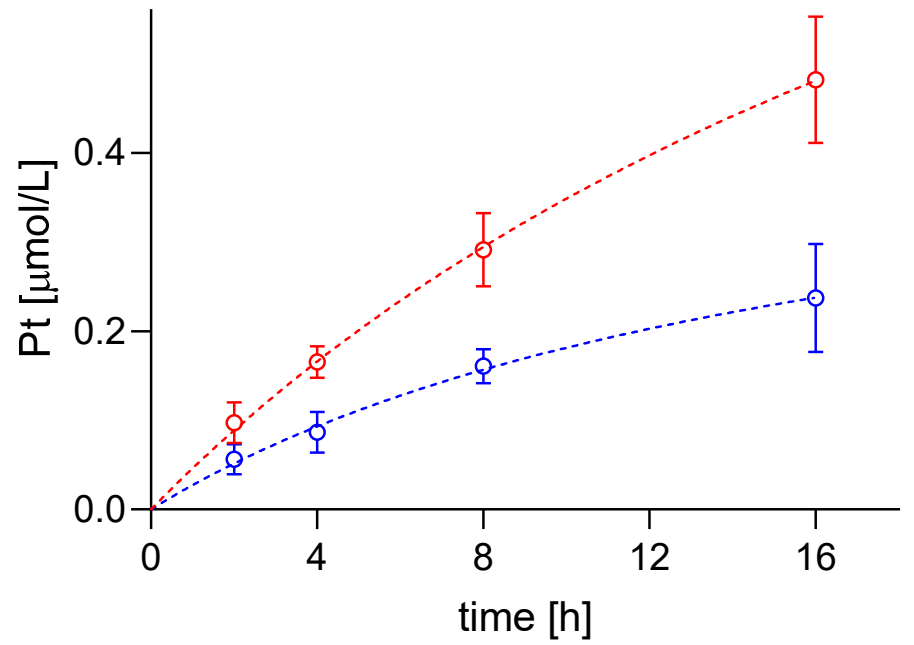

Figure 3. Timeline of cisPt uptake by $-\bullet-\mathrm{A} 24$ and $-\bullet-\mathrm{A} 24 \mathrm{dPt} 8$ cells after incubation with $30 \mu \mathrm{M}$ cisPt.

The observed ratios between the A24 and A24dPt8 cells were approximately two-fold higher in the wt cells compared to the resistant cells for each observed time point. 
Comparison of cisPt concentration in A24 cells and resistant cells showed that the mean cellular cisPt concentrations per cell were significantly different. Statistical analysis was performed with a multiple unpaired $t$-test. Statistical significance was determined by the Holm-Sidak method with alpha $=0.05$ (Holm 1979). The $p$ values obtained were $<0.02$ at $2 \mathrm{~h}$ incubation time with cisPt and $<0.001$ for 4,8 , and $16 \mathrm{~h}$, respectively.

\subsection{Difference in cisPt Uptake between wt and Resistant Cells}

Altered cisPt uptake among different sublines with graduated cisPt resistance was assessed in sublines A24dPt2 and A24dPt4 (previously described as (D-)Pt2.0A24 and (D-)Pt4.0A24 [23]), A24dPt8 and A24 cells incubated for $16 \mathrm{~h}$ with $30 \mu \mathrm{M}$ cisPt. The previously measured volume of the cells allowed for determination of the cellular cisPt concentration by SC-ICP-MS. No difference was detected in the uptake of cisPt between the A24 cells and the A24dPt2 cells with approximately $0.42 \mu \mathrm{M}$ cisPt per cell $(p>0.05)$. However, significantly lower cisPt uptake was observed for the A24dPt4 and A24dPt8 sublines with $0.24 \pm 0.03(p<0.01)$, and $0.17 \pm 0.01 \mu \mathrm{M}(p<0.01)$ cisPt, respectively (Figure 4$)$.

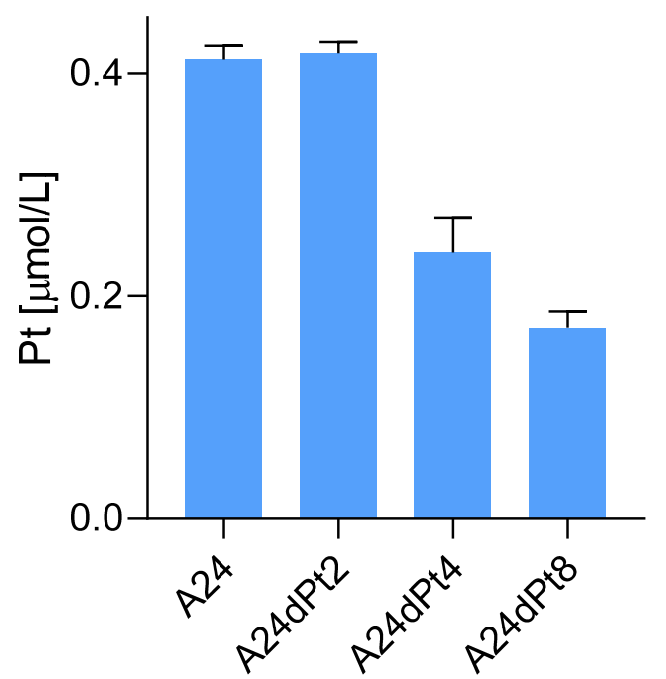

Figure 4. Cellular cisPt concentration in A24, A24dPt2, A24dPt4, and A24dPt8 cells after $16 \mathrm{~h}$ incubation with $30 \mu \mathrm{M}$ cisPt.

\subsection{Nuclear cisPt Concentration in A24 and A24dPt8 Cells}

As previously described [2], the cytotoxic action of cisPt on NSCLC is induced by binding of cisPt to DNA. Nuclei were isolated from cells that were treated with $30 \mu \mathrm{M}$ cisPt. Assessment of the purity of the nuclear extract was performed by Western blot verifying the absence of endoplasmic reticulum and cytosolic contaminants (Figure 5A). A nuclear marker (Lamin A/C, 63 and $74 \mathrm{kDa}$ ), an endoplasmic reticulum marker (SERCA 2 ATPase, $115 \mathrm{kDa}$ ), and a cytosolic marker (GAPDH, $40.2 \mathrm{kDa}$ ) were applied. Whole cell extracts, washed in PBS and re-suspended in RIPA buffer were used as positive controls (Figure 5A). Nuclear concentrations of cisPt were then calculated according to nuclei volumes (Figure 5B). Volumes up to $1800 \mu \mathrm{m}^{3}$ were observed with a mean of $600 \mu^{3}$ per nucleus in both cell sublines A24 wt and A24dPt8, respectively.

SC-ICP-MS was used to determine the concentration of cisPt in nuclei of A24 and A24dPt8 cells. For this purpose, A24 and A24dPt8 cells were exposed to $30 \mu \mathrm{M}$ cisPt for 8 and $16 \mathrm{~h}$. Subsequently, the cell nuclei were isolated and the amount of platinum per nucleus was measured. Similar to the cisPt concentration per cell, A24 and A24dPt8 nuclei showed varying amounts of cisPt within cell populations. Frequency histograms for $16 \mathrm{~h}$ incubation with cisPt obtained by SC-ICP-MS analysis are shown in Figure 6. Varying amounts of cisPt per nuclei were measured within both A24 and A24dPt8. 
A

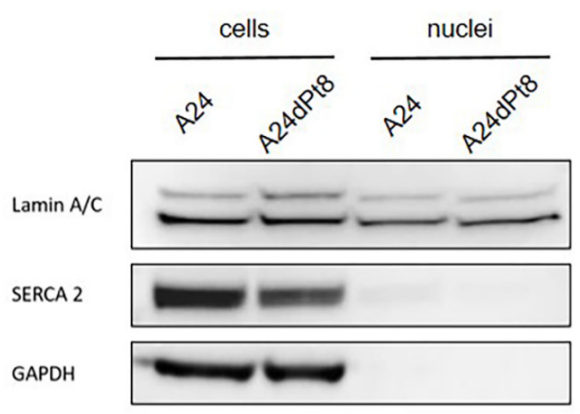

B

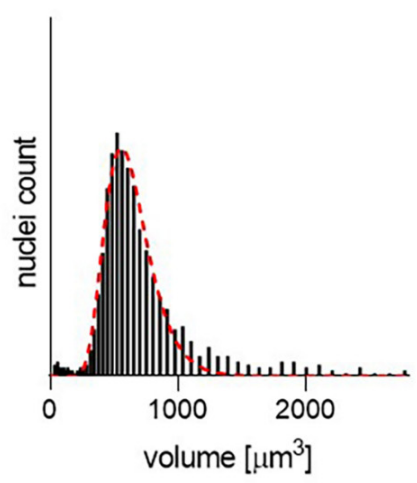

Figure 5. Isolation of intact nuclei. (A) The purity of the nuclear fraction was assessed using Lamin A/C (nuclear marker), SERCA2 ATPase (ER marker) and GAPDH (cytoplasmic marker) by Western blot. Column 1 and 2 show the cell extracts of A24 and A24dPt8, column 3 and 4 show the A24 isolated nuclei and the A24dPt8 isolated nuclei. (B) Representative volume distribution of isolated nuclei from A24 cells. The red curve shows the lognormal fit of the frequency.

A

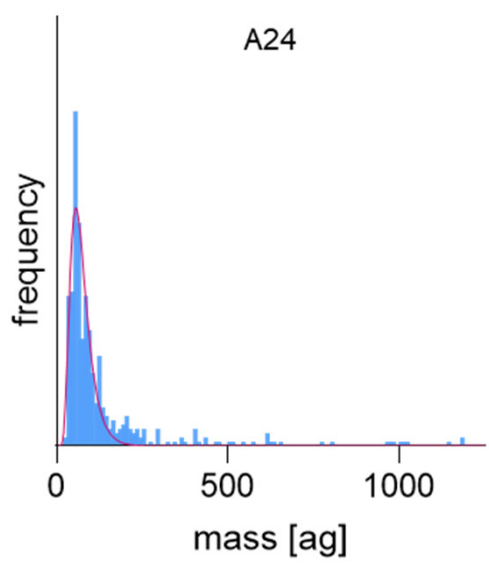

B

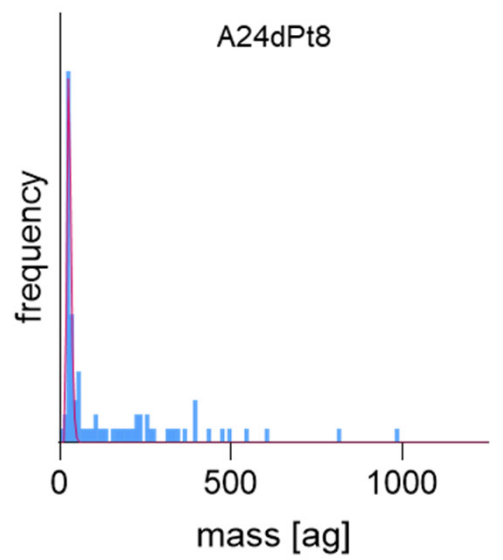

Figure 6. Frequency plots of isolated nuclei from (A) A24 cells and (B) A24dPt8 cells incubated with $30 \mu \mathrm{M}$ cisPt for $16 \mathrm{~h}$. The red curve shows the lognormal fit of the frequency.

Average concentration of cisPt in nuclei of sensitive and resistant cells were determined, using measured nuclear volumes. The average cisPt concentration detected by SC-ICP-MS for $8 \mathrm{~h}$ in A24 cells was $0.6 \pm 0.08 \mu \mathrm{M}$ cisPt per nucleus, and $1.02 \pm 0.27 \mu \mathrm{M}$ cisPt per nucleus after $16 \mathrm{~h}$ of incubation. In contrast, determination of nuclear cisPt concentration in resistant $\mathrm{A} 24 \mathrm{dPt} 8$ cells revealed an average concentration of $0.23 \pm 0.06 \mu \mathrm{M}$ cisPt per nucleus at $8 \mathrm{~h}$. At $16 \mathrm{~h}$, an average of $0.59 \pm 0.17 \mu \mathrm{M}$ cisPt per nucleus was detected. CisPt concentrations measured in nuclei or cells within the same cell line are significantly higher in nuclei than in cells. From SC-ICP-MS measurements, an approximate two-fold higher concentration of cisPt was found in nuclei compared to A24 cells at 8 and $16 \mathrm{~h}$, respectively (Figure 7). 


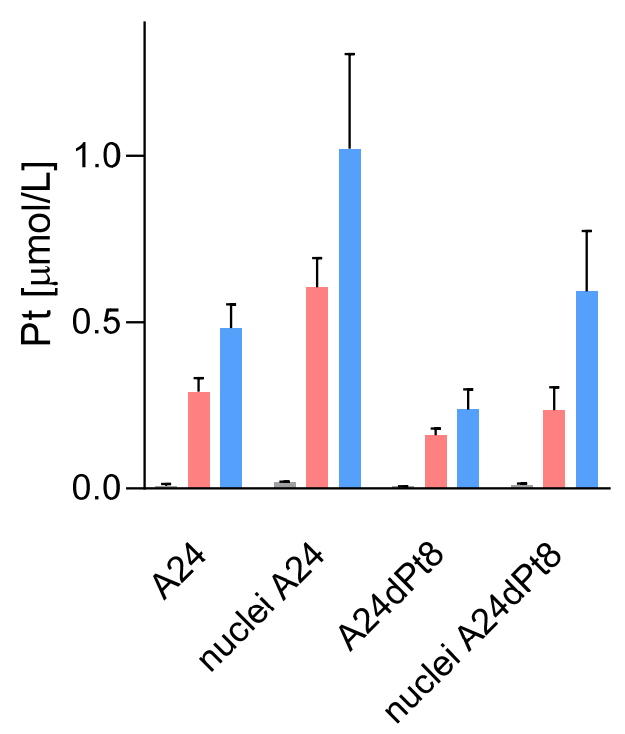

Figure 7. Nuclear and cellular cisPt concentration after incubation of A24 and A24dPt8 cells for 10 , 8 , and $16 \mathrm{~h}$ with $30 \mu \mathrm{M}$ cisPt.

\section{Discussion}

In the present study, cisPt accumulation in cells and nuclei of sensitive and resistant A24 sublines was analyzed by SC-ICP-MS. To date, platinum compounds are the gold standard of combined chemotherapy protocols for advanced lung cancer. ICP-MS is an element-specific analytical method that allows tracking of metallodrugs in biological samples and has become a routine method to determine drug accumulation and/or distribution in tissues or cells. However, cells can have significant heterogeneity, resulting in variable metal uptake. When performing quantitative analysis of metallodrugs by means of ICP-MS following digestion of targeted cells, this information is typically lost. However, SC-ICP-MS overcomes these conceptual shortcomings of standard analysis approaches, since it is capable to detect metal (e.g., Pt) contents of individual cells and therefore permits tracking and quantification of metallodrugs in biological samples [27]. The use of SC-ICP-MS allowed both, to determine the cisPt content of single cells and to quantify the cisPt present in individual extracted nuclei. Analysis of the cisPt concentration in both, cells and isolated nuclei, volume distribution of cell population and nuclei was considered.

Uptake of cisPt was determined in platinum-sensitive lung adenocarcinoma wt cells from an adrenal metastasis and the corresponding cisPt-resistant sublines. In a first series of experiments, SC-ICP-MS was used to measure the uptake of cisPt in A24 and A24dPt8 cells over time (Figures 2 and 3). A high mass dispersion was observed between A24 cells and A24dPt8 cells following a lognormal distribution. The volume was found to vary within cell populations and to follow a lognormal distribution as well (Figure 2B). It should also be kept in mind that this measurement method cannot exclude the possibility of cell aggregation, even though cells were passed through a 25-gauge needle prior to measurement. Since both cisPt uptake and cell volumes follow a lognormal distribution, the respective mean values were used to calculate intracellular cisPt concentrations.

Over time, an increase of the cisPt concentration was observed for both A24 and A24dPt8 cells. However, the uptake is significantly lower in the A24dPt8 cell line than compared to the wt-A24 cell line. Approximately twice the concentration of cisPt was measured in A24 wt cells as compared to resistant A24dPt8 cells at different time points. This difference in cisPt uptake is consistent with several studies comparing cisPt accumulation in resistant and sensitive cell lines [28-32]. The difference in concentration of cisPt in resistant cells compared to $\mathrm{A} 24 \mathrm{wt}$ cells can be explained by less cisPt uptake, excretion, or both. In different cell types, under-expression of membrane transporters or overexpression of drug efflux pumps contributes to less Pt accumulation within the cell [33,34]. After 
incubation with $30 \mu \mathrm{M}$ cisPt for $0,2,4,8$ and $16 \mathrm{~h}$, the resulting curves for A24 and A24dPt8 show a pattern of saturation for cisPt in the resistant and sensitive cell sublines.

Uptake of cisPt was measured after $16 \mathrm{~h}$ of incubation with $30 \mu \mathrm{M}$ cisPt in A24, $\mathrm{A} 24 \mathrm{dPt} 8$, and two additional resistant cell lines A24dPt2 and A24dPt4 (Figure 4). The intracellular concentration of cisPt decreased with increased resistance. A24dPt8 showed a concentration of $0.17 \mu \mathrm{M}$, while A24 showed concentrations above $0.4 \mu \mathrm{M}$. Intermediate resistant cells A24dPt4 showed intracellular concentrations of cisPt $(0.24 \mu \mathrm{M})$. A24dPt2 cells exhibited intracellular concentrations of cisPt similar to A24. Hence, uptake of cisPt correlates with resistance of the cell subline cultured in increasing concentrations of cisPt for a prolonged time. Because resistance due to cisPt induction of cells increases, the uptake of cisPt decreases. These findings suggest that cisPt resistance is partially due to reduced cisPt import by the cells. This reduction could be explained by an altered transport mechanism of cisPt into the cells or by an additional excretion mechanism. However, lower uptake of cisPt is not sufficient to explain the development of resistance to cisPt. This is because a significant concentration of cisPt was still measured in resistant cells. Thus, epigenetic modifications, e.g., DNA methylation [33,35], structural changes in chromatin $[33,36,37]$ or histone modifications $[33,38]$ may confer resistance to cisPt. Additional mechanisms of resistance to cisPt have been reported, such as transcription factors [33,39], gene regulation by microRNA [33,40], or expression of proteins involved in susceptibility or against DNA damage [33].

According to previous studies, cisPt targets the nucleus by binding to nucleotide base nitrogen residues [2]. In ovarian cancer cells (A2780), concentrated levels of Pt were found in the nucleus with hotspots in the nucleolus, which may suggest a role for cisPt in modulating protein production through interactions with RNA and ribosome synthesis [33]. To our knowledge, cell organelles, namely cell nuclei, were investigated for the first time by SC-ICP-MS. Purified nuclei from A24 or A24dPt8 cells treated initially with $30 \mu \mathrm{M}$ cisPt were analyzed by Western blot verifying the purity (Figure 5). CisPt uptake in cell nuclei was determined by SC-ICP-MS (Figure 7). Comparable to the whole cell analysis, the dispersion was more pronounced in A24 wt cell nuclei compared to $\mathrm{A} 24 \mathrm{dPt} 8$ cell nuclei. The cell nuclei size was heterogeneous; hence, the average volume was used to calculate the concentration of cisPt. A significantly higher concentration of cisPt was determined in the A24 wt cell nuclei compared to A24dPt8 cell nuclei. The concentration of cisPt was approximately two-fold higher in the A24 wt nuclei than compared to resistant nuclei. However, the cisPt present in the resistant cells is imported into the nucleus at approximately the same ratio as in $\mathrm{A} 24$ cells. It was found that the concentration of cisPt within the nucleus is approximately two-fold higher compared with the cell concentration in A24 cells and in A24dPt8 cells. This observation supports the theory of binding of cisPt to DNA, resulting in a higher concentration of cisPt in cell nuclei compared to the extranuclear cell space. The increase in Pt concentration within the nucleus becomes even more prominent if the mass balance, that can be calculated from the concentration and volumes of the cells and nucleus, respectively, is considered. Furthermore, we concluded that the uptake mechanism of cisPt into the nucleus of resistant cells is not different from that of sensitive cells, and passive diffusion occurs most probably through the nuclear pore [41]. The amount of cisPt detected in the nuclei of resistant cells after $16 \mathrm{~h}$ of incubation is similar to the amount observed in wt nuclei after $8 \mathrm{~h}$ of incubation with cisPt. The relatively high concentration of cisPt in the resistant cell nuclei underpins that cisPt resistance in NSCLC is due to a multifaceted mechanism [42].

In conclusion, significant less cisPt was detected in resistant A24 cells than compared to A24-wt cells. It has been shown that SC-ICP-MS can also measure metal drugs in isolated cell organelles, such as cell nuclei. This study demonstrated that metals above a certain detection limit can be measured in subcellular compartments by SC-ICP-MS. However, only one subcellular compartment was studied in these experiments; namely, the nucleus. Other subcellular compartments are of interest, but currently the detection limit of the instrument is a limiting factor. In addition, it was shown that the difference in cisplatin 
uptake by the cells strongly correlates with different cell volumes. Demonstrated by using lognormal distribution, thus showing that a heterogeneous distribution of cisplatin uptake into cells is unlikely due to some other unknown mechanism. In conventional ICP-MS, this information is lost because it is a mass analysis. Overall, the SC-ICP-MS method allowed a faster quantification of intracellular and nuclear Pt concentrations than classical ICPMS because pelleted cells or nuclei were resuspended directly in water and PBS without the need of fixation. Moreover, there is no loss of intracellular metal because there is no membrane permeabilization in SC-ICP-MS, which is a common shortcoming in ICP-MS. These findings pave the way for future applications investigating the potency and efficacy of novel metallodrugs developed for precision medicine.

\section{Materials and Methods}

\subsection{Cell Cultivation}

$\mathrm{A} 24, \mathrm{~A} 24 \mathrm{dPt} 2, \mathrm{~A} 24 \mathrm{dPt} 4$, and A24dPt8 were included for evaluation of cisPt accumulation in this study [23]. The A24 sublines, were cultured in RPMI 1640 without riboflavin, phenol red, and antibiotics, buffered with $4.5 \mathrm{mM}$ HEPES (BioConcept, Allschwil, Switzerland), supplemented with $10 \%(v / v)$ fetal bovine serum (FBS) (Thermo Scientific, Waltham, MA, USA) as the only source of flavins, and $13.5 \mathrm{mM} \mathrm{NaHCO}_{3}$. At subcultivation, cell monolayers were rinsed with PBS and exposed for $3 \mathrm{~min}$ to StemPro Accutase Cell Dissociation Reagent (Thermo Scientific, Waltham, MA, USA) at $36.5^{\circ} \mathrm{C}$. Detached cells were re-suspended in culture medium. Cell densities were determined using MoxiFlow cytometer according to manufacturer instructions (Orflo Technologies, Ketchum, ID, USA). Experiments and subcultivations were performed using light with wavelengths above $520 \mathrm{~nm}$ to prevent photochemical artifacts [43]. Culture vessels and test plates were incubated in the dark at $36.5^{\circ} \mathrm{C}$ below 3.5 percent $\mathrm{CO}_{2}(v / v)$ and humidified air.

\subsection{Cell Preparation for SC-ICP-MS}

One day before starting the experiments, $5.5 \times 10^{5}$ cells $/ \mathrm{mL}$ were plated in 6 well plates. Then, $30 \mu \mathrm{M}$ cisPt (Sandoz, Holzkirchen, Germany) was added and incubated for either $5 \mathrm{~min}, 2,4,8$ or $16 \mathrm{~h}$ under standard conditions. Cells were washed twice with ice-cold PBS (Gibco, NY, USA) and detached with $0.5 \mathrm{~mL}$ of StemPro Accutase Cell Dissociation Reagent in order to remove any cisPt adsorbed to the cell wall. Detached cells were resuspended in culture media and cell density, as well as cell volume, was measured using the MoxiFlow cytometer according to the manufacturer's instructions (Orflo Technologies, Ketchum, ID, USA) [23]. $5.5 \times 10^{5}$ cells were centrifuged for $5 \mathrm{~min}$ at $500 \mathrm{~g}$ and $4{ }^{\circ} \mathrm{C}$. Supernatant was discarded and the pellet was washed once with PBS. Pellets were kept on ice until measurement.

\subsection{Nuclei Isolation for SC-ICP-MS Analysis}

Nuclei isolation was performed as described previously with minor modifications using Nuclei isolation Kit: Nuclei EZ Prep (Merck KGaA, Darmstadt, Germany) [44]. Briefly, $10^{6} \mathrm{~A} 24$ or A24dPt8 cells were washed twice with PBS. The pellet was resuspended in EZ Lysis Buffer, vortexed and incubated on ice for $5 \mathrm{~min}$. Afterwards the sample was centrifuged at $500 \mathrm{~g}$ for $5 \mathrm{~min}$ at $4{ }^{\circ} \mathrm{C}$. This step was repeated one. The pellet was resuspended in $500 \mu \mathrm{L}$ EZ buffer containing $0.25 \mathrm{M}$ sucrose and layered on top of $500 \mu \mathrm{L}$ EZ buffer containing $0.5 \mathrm{M}$ sucrose. Finally, the nuclei were obtained by centrifugation at $500 \mathrm{~g}$ for $10 \mathrm{~min}$ at $4{ }^{\circ} \mathrm{C}$ and washed once with EZ buffer. Nuclei were re-suspended in PBS. Number of nuclei and nuclei volumes were determined using an automated particles counter (Orflo technologies, Ketchum, ID, USA). Samples were kept on ice.

\subsection{SC-ICP-MS Measurements}

Single cell ICP-MS experiment were performed using Perkin Elmer's NexION ICP-MS (Perkin Elmer Waltham, MA, USA) which was set up with specific material for single cell experiments as previously described and with minor modifications [45]. The instrumental 
conditions applied are shown in Table 1 . The transport efficiency was calibrated with 50-nm gold nanoparticles (NanoComposix, San Diego, CA, USA) with a concentration of $10^{5}$ particles $/ \mathrm{mL}$. The device was calibrated for platinum using standard solutions prepared in $2 \% \mathrm{HNO}_{3}$ with $1,5,10$, and $20 \mathrm{ppb} \mathrm{Pt}$. To generate the calibration curve, averaged intensities for Pt over a measuring time of $60 \mathrm{~s}$ were used. Cells or nuclei were re-suspended in PBS and 1:3 diluted in $\mathrm{H}_{2} \mathrm{O}$ resulting in a final concentration of $10^{5}$ particles $/ \mathrm{mL}$. Cells were passed through a 25-gauge needle prior to measurement. Every experiment was performed in triplicates at least. Results were processed using the Syngistix ${ }^{\mathrm{TM}}$ Single Cell Application Software (Perkin Elmer, Waltham, MA, USA).

Table 1. SC-ICP-MS conditions.

\begin{tabular}{cc}
\hline Parameter & Value \\
\hline Sample Uptake Rate & $10 \mu \mathrm{L} / \mathrm{min}$ \\
Nebulizer & N8152496 REV A CytoNeb \\
Spray chamber & Asperon \\
Injector & $2.0 \mathrm{~mm}$ id Quartz \\
Sample Line & N8152489 REV A \\
RF Power & $1600 \mathrm{~W}$ \\
Neb Gas Flow & $0.38-0.42 \mathrm{~L} / \mathrm{min}$ \\
Makeup Gas Flow & $0.61 \mathrm{~L} / \mathrm{min}$ \\
Platinum Isotope & $195 \mathrm{amu}$ \\
Dwell time & $50 \mu \mathrm{s}$ \\
Sample Analysis Time & $100 \mathrm{~s}$ \\
\hline
\end{tabular}

\subsection{Western Blotting}

Protein purity and absence of cytoplasmic contamination, was assessed with antibodies against lamin A/C (inner nuclear membrane marker), SERCA2 ATPase (endoplasmic reticulum marker), and GAPDH (cytoplasmic marker) using Western blotting as described elsewhere [44]. These antibodies were obtained from Abcam (Abcam, Cambridge, UK). After washing the cells in ice-cold PBS, the cell pellet was resuspended in Triton based RIPA lysis buffer supplemented with the protease inhibitor cocktail, complete Mini, EDTA-free (Merck KGaA, Darmstadt, Germany). Lysates were centrifuged at $8609 \mathrm{rcf}$ and the supernatant was mixed with NuPAGE ${ }^{\mathrm{TM}}$ LDS Sample Buffer supplemented with NuPAGE ${ }^{\mathrm{TM}}$ Sample Reducing Agent (Thermo Scientific, Waltham, MA, USA). SDS-PAGE was performed using NuPAGE ${ }^{\mathrm{TM}} 4-12 \%$ Bis-Tris gels and NuPAGE ${ }^{\mathrm{TM}}$ MOPS SDS running buffer (Thermo Scientific, Waltham, MA, USA). Proteins were transferred using activated porous $0.45 \mu \mathrm{m}$ polyvinylidene fluoride (PVDF) membranes (Thermo Scientific, Waltham, MA, USA). After blocking the membranes in TBS-T (0.15 M NaCl, $50 \mathrm{mM}$ Tris- $\mathrm{HCl}, 0.1 \%$ Tween 20, $\mathrm{pH} 7.6$ ) containing $5 \%$ milk powder and $1 \%$ bovine serum albumin (Merck KGaA, Darmstadt, Germany), a primary antibody was used to detect the protein of interest. After washing the membranes with TBS-T, they were incubated with secondary horse radish-peroxidase conjugated secondary antibodies (Agilent technologies Dako, Santa Clara, CA, USA). Membranes were developed using SuperSignal ${ }^{\circledR}$ West Dura Extended Duration Substrate (Thermo Scientific, Waltham, MA, USA) and visualized using Gel Documentation system Fusion-FX7-820 (Vilber Lourmat Sté, Collégien, France)

\subsection{Statistics}

Multiple unpaired $t$ tests were performed using GraphPad Prism 8.0 Software [46].

Author Contributions: Conceptualization, A.G., N.R., N.L., M.N.H. and C.K.; Data curation, A.G., N.R., M.N.H. and C.K.; Formal analysis, A.G., N.R., M.N.H. and C.K.; Investigation, N.R. and C.K.; Methodology, N.R., M.N.H. and C.K.; Supervision, J.T.H. and H.v.T.-K.; Visualization, N.R. and C.K.; Writing—original draft, A.G., N.R., P.B. and L.H.; Writing—review \& editing, P.B., L.H., C.K., J.T.H. and H.v.T.-K. All authors have read and agreed to the published version of the manuscript.

Funding: This research received no external funding. 
Institutional Review Board Statement: Not applicable.

Informed Consent Statement: Not applicable.

Data Availability Statement: The data presented in this study are available on request from the corresponding author.

Acknowledgments: We would like to thank PerkinElmer for technical support.

Conflicts of Interest: The authors declare no conflict of interest.

\section{References}

1. Simpson, P.V.; Desai, N.M.; Casari, I.; Massi, M.; Falasca, M. Metal-based antitumor compounds: Beyond cisplatin. Futur. Med. Chem. 2019, 11, 119-135. [CrossRef]

2. Galluzzi, L.; Senovilla, L.; Vitale, I.; Michels, J.; Martins, I.; Kepp, O.; Castedo, M.; Kroemer, G. Molecular mechanisms of cisplatin resistance. Oncogene 2011, 31, 1869-1883. [CrossRef] [PubMed]

3. Kelland, L. The resurgence of platinum-based cancer chemotherapy. Nat. Rev. Cancer 2007, 7, 573-584. [CrossRef]

4. Siddik, Z.H. Cisplatin: Mode of cytotoxic action and molecular basis of resistance. Oncogene 2003, 22, 7265-7279. [CrossRef] [PubMed]

5. Kelland, L.R. Preclinical perspectives on platinum resistance. Drugs 2000, 59, 1-8. [CrossRef]

6. Yoshida, M.; Khokhar, A.R.; Siddik, Z.H. Biochemical pharmacology of homologous alicyclic mixed amine platinum (II) complexes in sensitive and resistant tumor cell lines. Cancer Res. 1994, 54, 3468-3473. [PubMed]

7. Kalayda, G.V.; Wagner, C.H.; Jaehde, U. Relevance of copper transporter 1 for cisplatin resistance in human ovarian car-cinoma cells. J. Inorg. Biochem. 2012, 116, 1-10. [CrossRef] [PubMed]

8. Shenberger, Y.; Shimshi, A.; Ruthstein, S. EPR spectroscopy shows that the blood carrier protein, human serum albumin, closely interacts with the N-terminal domain of the copper transporter, Ctr1. J. Phys. Chem. B 2015, 119, 4824-4830. [CrossRef] [PubMed]

9. Samimi, G.; Safaei, R.; Katano, K.; Holzer, A.K.; Rochdi, M.; Tomioka, M.; Goodman, M.; Howell, S.B. Increased expression of the copper efflux transporter ATP7A mediates resistance to cisplatin, carboplatin, and oxaliplatin in ovarian cancer cells. Clin. Cancer Res. 2004, 10, 4661-4669. [CrossRef]

10. Qasem, Z.; Pavlin, M.; Ritacco, I.; Gevorkyan-Airapetov, L.; Magistrato, A.; Ruthstein, S. The pivotal role of MBD4-ATP7B in the human $\mathrm{Cu}(\mathrm{I})$ excretion path as revealed by EPR experiments and all-atom simulations. Metallomics 2019, 11, 1288-1297. [CrossRef]

11. Wessels, L.F.; Voss, F.K.; Ullrich, F.; Xu, G.; Blomen, V.A.; Borst, P.; Gerhards, N.M.; Rottenberg, S.; Lutter, D.; Guyader, C.; et al. Subunit composition of VRAC channels determines substrate specificity and cellular resistance to $\mathrm{P}$ t-based anti-cancer drugs. EMBO J. 2015, 34, 2993-3008. [CrossRef]

12. Rabik, C.; Dolan, M.E. Molecular mechanisms of resistance and toxicity associated with platinating agents. Cancer Treat. Rev. 2007, 33, 9-23. [CrossRef]

13. Kartalou, M.; Essigmann, J.M. Mechanisms of resistance to cisplatin. Mutat. Res. 2001, 478, 23-43. [CrossRef]

14. Galluzzi, L.; Vitale, I.; Michels, J.; Brenner, C.; Szabadkai, G.; Harel-Bellan, A.; Castedo, M.; Kroemer, G. Systems biology of cisplatin resistance: Past, present and future. Cell Death Dis. 2014, 5, e1257. [CrossRef] [PubMed]

15. Fennell, D.; Summers, Y.; Cadranel, J.; Benepal, T.; Christoph, D.; Lal, R.; Das, M.; Maxwell, F.; Visseren-Grul, C.; Ferry, D. Cisplatin in the modern era: The backbone of first-line chemotherapy for non-small cell lung cancer. Cancer Treat. Rev. 2016, 44, 42-50. [CrossRef] [PubMed]

16. Voets, T.; Nilius, B.; Vennekens, R. VRAC s swallow platinum drugs. EMBO J. 2015, 34, 2985-2987. [CrossRef]

17. Bray, F.; Ferlay, J.; Soerjomataram, I.; Siegel, R.L.; Torre, L.A.; Jemal, A. Global cancer statistics 2018: GLOBOCAN estimates of incidence and mortality worldwide for 36 cancers in 185 countries. CA Cancer J. Clin. 2018, 68, 394-424. [CrossRef] [PubMed]

18. Pirker, R. Conquering lung cancer: Current status and prospects for the future. Pulmonology 2020, 26, 283-290. [CrossRef]

19. Pirker, R. Biomarkers for immune checkpoint inhibitors in advanced nonsmall cell lung cancer. Curr. Opin. Oncol. 2019, 31, 24-28. [CrossRef]

20. Lai, G.-M.; Ozols, R.F.; Smyth, J.F.; Young, R.C.; Hamilton, T.C. Enhanced DNA repair and resistance to cisplatin in human ovarian cancer. Biochem. Pharmacol. 1988, 37, 4597-4600. [CrossRef]

21. Fujii, R.; Mutoh, M.; Sumizawa, T.; Chen, Z.-S.; Yoshimura, A.; Akiyama, S.-I. Adenosine triphosphate-dependent transport of leukotriene $\mathrm{C} 4$ by membrane vesicles prepared from cisplatin-resistant human epidermoid carcinoma tumor cells. J. Natl. Cancer Inst. 1994, 86, 1781-1784. [CrossRef]

22. Twentyman, P.R.; Wright, K.A.; Mistry, P.; Kelland, L.R.; Murrer, B.A. Sensitivity to novel platinum compounds of panels of human lung cancer cell lines with acquired and inherent resistance to cisplatin. Cancer Res. 1992, 52, 5674-5680. [PubMed]

23. Ruprecht, N.; Hofmann, L.; Hungerbühler, M.N.; Kempf, C.; Heverhagen, J.T.; von Tengg-Kobligk, H. Generation of stable cisPt resistant lung adenocarcinoma cells. Pharmaceuticals 2020, 13, 109. [CrossRef] [PubMed]

24. Sørensen, B.H.; Thorsteinsdottir, U.A.; Lambert, I.H. Acquired cisplatin resistance in human ovarian A2780 cancer cells correlates with shift in taurine homeostasis and ability to volume regulate. Am. J. Physiol. Cell Physiol. 2014, 307, C1071-C1080. [CrossRef] 
25. Sørensen, B.H.; Dam, C.S.; Stürup, S.; Lambert, I.H. Dual role of LRRC8A-containing transporters on cisplatin resistance in human ovarian cancer cells. J. Inorg. Biochem. 2016, 160, 287-295. [CrossRef] [PubMed]

26. Sørensen, B.H.; Nielsen, D.; Thorsteinsdottir, U.A.; Hoffmann, E.K.; Lambert, I.H. Downregulation of LRRC8A protects human ovarian and alveolar carcinoma cells against Cisplatin-induced expression of p53, MDM2, p21Waf1/Cip1, and Caspase-9/-3 activation. Am. J. Physiol. Cell Physiol. 2016, 310, C857-C873. [CrossRef]

27. Theiner, S.; Loehr, K.; Koellensperger, G.; Mueller, L.; Jakubowski, N. Single-cell analysis by use of ICP-MS. J. Anal. At. Spectrom. 2020, 35, 1784-1813. [CrossRef]

28. Liang, X.-J.; Shen, D.-W.; Chen, K.G.; Wincovitch, S.M.; Garfield, S.H.; Gottesman, M.M. Trafficking and localization of platinum complexes in cisplatin-resistant cell lines monitored by fluorescence-labeled platinum. J. Cell. Physiol. 2004, 202, 635-641. [CrossRef]

29. Chen, K.; Valencia, J.C.; Lai, B.; Zhang, G.; Paterson, J.K.; Rouzaud, F.; Berens, W.; Wincovitch, S.M.; Garfield, S.H.; Leapman, R.; et al. Melanosomal sequestration of cytotoxic drugs contributes to the intractability of malignant melanomas. Proc. Natl. Acad. Sci. USA 2006, 103, 9903-9907. [CrossRef]

30. Groessl, M.; Zava, O.; Dyson, P. Cellular uptake and subcellular distribution of ruthenium-based metallodrugs under clinical investigation versus cisplatin. Metallomics 2011, 3, 591-599. [CrossRef]

31. Hall, M.D.; Dillon, C.T.; Zhang, M.; Beale, P.; Cai, Z.; Lai, B.; Stampfl, A.P.J.; Hambley, T.W. The cellular distribution and oxidation state of platinum (II) and platinum (IV) antitumour complexes in cancer cells. J. Biol. Inorg. Chem. 2003, 8, 726-732. [CrossRef]

32. Corte-Rodríguez, M.; Álvarez-Fernández García, R.; Blanco, E.; Bettmer, J.; Montes-Bayón, M. Quantitative evaluation of cisplatin uptake in sensitive and resistant individual cells by single-cell ICP-MS (SC-ICP-MS). Anal. Chem. 2017, 89, 11491-11497. [CrossRef] [PubMed]

33. Lee, R.F.S.; Riedel, T.; Escrig, S.; Maclachlan, C.; Knott, G.W.; Davey, C.A.; Johnsson, K.; Meibom, A.; Dyson, P.J. Differences in cisplatin distribution in sensitive and resistant ovarian cancer cells: A TEM/NanoSIMS study. Metallomics 2017, 9, 1413-1420. [CrossRef] [PubMed]

34. Amable, L. Cisplatin resistance and opportunities for precision medicine. Pharmacol. Res. 2016, 106, 27-36. [CrossRef] [PubMed]

35. Chang, X.; Monitto, C.L.; Demokan, S.; Kim, M.S.; Chang, S.S.; Zhong, X.; Califano, J.A.; Sidransky, D. Identification of hypermethylated genes associated with cisplatin resistance in human cancers. Cancer Res. 2010, 70, 2870-2879. [CrossRef]

36. Sharma, S.V.; Lee, D.Y.; Li, B.; Quinlan, M.P.; Takahashi, F.; Maheswaran, S.; McDermott, U.; Azizian, N.; Zou, L.; Fischbach, M.A.; et al. A chromatin-mediated reversible drug-tolerant state in cancer cell subpopulations. Cell 2010, 141, 69-80. [CrossRef]

37. Wang, Q.-E.; Han, C.; Milum, K.; Wani, A.A. Stem cell protein Piwil2 modulates chromatin modifications upon cisplatin treatment. Mutat. Res. Mol. Mech. Mutagen. 2011, 708, 59-68. [CrossRef] [PubMed]

38. Miyamoto, N.; Izumi, H.; Noguchi, T.; Nakajima, Y.; Ohmiya, Y.; Shiota, M.; Kidani, A.; Tawara, A.; Kohno, K. Tip60 is regulated by circadian transcription factor clock and is involved in cisplatin resistance. J. Biol. Chem. 2008, 283, 18218-18226. [CrossRef]

39. Hirano, G.; Izumi, H.; Kidani, A.; Yasuniwa, Y.; Han, B.; Kusaba, H.; Akashi, K.; Kuwano, M.; Kohno, K. Enhanced expression of PCAF endows apoptosis resistance in cisplatin-resistant cells. Mol. Cancer Res. 2010, 8, 864-872. [CrossRef]

40. Hamano, R.; Miyata, H.; Yamasaki, M.; Sugimura, K.; Tanaka, K.; Kurokawa, Y.; Nakajima, K.; Takiguchi, S.; Fujiwara, Y.; Mori, M.; et al. High expression of Lin28 is associated with tumour aggressiveness and poor prognosis of patients in oesophagus cancer. Br. J. Cancer 2012, 106, 1415-1423. [CrossRef]

41. Timney, B.L.; Raveh, B.; Mironska, R.; Trivedi, J.M.; Kim, S.J.; Russel, D.; Wente, S.R.; Sali, A.; Rout, M.P. Simple rules for passive diffusion through the nuclear pore complex. J. Cell Biol. 2016, 215, 57-76. [CrossRef] [PubMed]

42. Kryczka, J.; Kryczka, J.; Czarnecka-Chrebelska, K.H.; Brzeziańska-Lasota, E. Molecular mechanisms of chemoresistance induced by cisplatin in NSCLC cancer therapy. Int. J. Mol. Sci. 2021, 22, 8885. [CrossRef] [PubMed]

43. Granzow, C.; Kopun, M.; Kröber, T. Riboflavin-mediated photosensitization of Vinca alkaloids distorts drug sensitivity assays. Cancer Res. 1995, 55, 4837-4843. [PubMed]

44. Caliaro, O.; Marti, A.; Ruprecht, N.; Leisi, R.; Subramanian, S.; Hafenstein, S.; Ros, C. Parvovirus B19 uncoating occurs in the cytoplasm without capsid disassembly and it is facilitated by depletion of capsid-associated divalent cations. Viruses 2019, 11, 430. [CrossRef] [PubMed]

45. Amable, L.; Smith, S.; Stephan, C. New Research Evaluating Cisplatin Uptake in Ovarian Cancer Cells by Single Cell ICP-MS. 2017. Available online: https:/ / resources.perkinelmer.com/lab-solutions/resources/docs/APP-NexION-2000-ICP-MS-SingleCell-Cancer-Research-013176_01.pdf (accessed on 30 August 2021).

46. Holm, S. A simple sequentially rejective multiple test procedure. Scand. J. Stat. 1979, 6, 65-70. 